\title{
Front Matter: Volume 6864
}

, "Front Matter: Volume 6864," Proc. SPIE 6864, Biomedical Applications of Light Scattering II, 686401 (11 March 2008); doi: 10.1117/12.792488

SPIE. Event: SPIE BiOS, 2008, San Jose, California, United States 


\section{PROGRESS IN BIOMEDICAL OPTICS AND IMAGING}

Vol. 9, No. 23

\section{Biomedical Applications of Light Scattering II}

Adam Wax

Vadim Backman

Editors

19-21 January 2008

San Jose, California, USA

Sponsored and Published by

SPIE

Volume 6864

Proceedings of SPIE, 1605-7422, v. 6864

SPIE is an international society advancing an interdisciplinary approach to the science and application of light. 
The papers included in this volume were part of the technical conference cited on the cover and title page. Papers were selected and subject to review by the editors and conference program committee. Some conference presentations may not be available for publication. The papers published in these proceedings reflect the work and thoughts of the authors and are published herein as submitted. The publisher is not responsible for the validity of the information or for any outcomes resulting from reliance thereon.

Please use the following format to cite material from this book:

Author(s), "Title of Paper," in Biomedical Applications of Light Scattering II, edited by Adam Wax, Vadim Backman, Proceedings of SPIE Vol. 6864 (SPIE, Bellingham, WA, 2008) Article CID Number.

ISSN $1605-7422$

ISBN 9780819470393

Published by

SPIE

P.O. Box 10, Bellingham, Washington 98227-0010 USA

Telephone +1 3606763290 (Pacific Time) · Fax +1 3606471445

SPIE.org

Copyright @ 2008, Society of Photo-Optical Instrumentation Engineers.

Copying of material in this book for internal or personal use, or for the internal or personal use of specific clients, beyond the fair use provisions granted by the U.S. Copyright Law is authorized by SPIE subject to payment of copying fees. The Transactional Reporting Service base fee for this volume is $\$ 18.00$ per article (or portion thereof), which should be paid directly to the Copyright Clearance Center (CCC), 222 Rosewood Drive, Danvers, MA 01923. Payment may also be made electronically through CCC Online at copyright.com. Other copying for republication, resale, advertising or promotion, or any form of systematic or multiple reproduction of any material in this book is prohibited except with permission in writing from the publisher. The CCC fee code is 1605$7422 / 08 / \$ 18.00$.

Printed in the United States of America.

Publication of record for individual papers is online in the SPIE Digital Library.

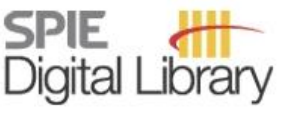

SPIEDigitalLibrary.org

Paper Numbering: Proceedings of SPIE follow an e-First publication model, with papers published first online and then in print and on CD-ROM. Papers are published as they are submitted and meet publication criteria. A unique, consistent, permanent citation identifier (CID) number is assigned to each article at the time of the first publication. Utilization of CIDs allows articles to be fully citable as soon they are published online, and connects the same identifier to all online, print, and electronic versions of the publication. SPIE uses a six-digit CID article numbering system in which:

- The first four digits correspond to the SPIE volume number.

- The last two digits indicate publication order within the volume using a Base 36 numbering system employing both numerals and letters. These two-number sets start with 00, 01, 02, 03, 04 , 05, 06, 07, 08, 09, 0A, OB ... 0Z, followed by 10-1Z, 20-2Z, etc.

The CID number appears on each page of the manuscript. The complete citation is used on the first page, and an abbreviated version on subsequent pages. Numbers in the index correspond to the last two digits of the six-digit CID number. 


\section{Contents}

vii Conference Committee

SESSION 1 NEW APPROACHES

686402 A raster scanning reflectance imager for non-model based quantification of tissue scatter [6864-01]

V. Krishnaswamy, Dartmouth College (USA); P. J. Hoopes, Dartmouth College (USA) and Dartmouth Medical School (USA); K. S. Samkoe, Dartmouth College (USA); B. W. Pogue, Dartmouth College (USA) and Dartmouth Medical School (USA)

686406 Detection of partial-thickness tears in ligaments and tendons by Stokes-polarimetry imaging [6864-05]

J. Kim, R. John, J. T. Walsh, Northwestern Univ. (USA)

\section{SESSION 2 LOW COHERENCE LIGHT SCATTERING}

686407 Interferometric synthetic aperture microscopy: tissue structure inferred by computed imaging techniques (Invited Paper) [6864-06]

D. L. Marks, T. S. Ralston, B. J. Davis, P. S. Carney, S. A. Boppart, Univ. of Illinois at Urbana-Champaign (USA)

686408 Propagation properties of 1300-nm light in blood-saline mixtures determined through optical coherence tomography [6864-07]

D. P. Popescu, B. Schattka, M. D. Hewko, J. Friesen, M. G. Sowa, National Research Council Canada (Canada)

686409 Detection of structural and functional changes in biological materials using angle-resolved low coherence interferometry (Invited Paper) [6864-08]

K. J. Chalut, Duke Univ. (USA); J. H. Ostrander, A. Wax, Duke Univ. Medical Ctr. (USA)

\section{SESSION 3 CLINICAL AND PRECLINICAL STUDIES}

$6864 \mathrm{OB} \quad$ Measuring tissue optical properties in vivo using reflectance-mode confocal microscopy and OCT [6864-10]

S. L. Jacques, R. Samatham, N. Choudhury, Y. Fu, D. Levitz, Oregon Health and Science Univ. (USA)

6864 OC Improving colorectal cancer screening: fact and fantasy (Invited Paper) [6864-11] J. Van Dam, Stanford Univ. School of Medicine (USA)

6864 OD Development of a clinical Fourier-domain angle resolved low-coherence interferometry system for in vivo measurements [6864-12]

N. G. Terry, Y. Zhu, W. J. Brown, A. Wax, Duke Univ. (USA) 
$6864 \mathrm{OE}$ Non-invasive monitoring and quantitative analysis of patch test reactions by reflectance spectrophotometry, laser Doppler flowmetry and transepidermal water loss [6864-13]

N. S. Eikje, Waseda Univ. (Japan) and The Univ. of Tokushima School of Medicine (Japan);

S. Arase, The Univ. of Tokushima School of Medicine (Japan)

\section{SESSION 4 THEORY}

6864 OG Particle shape as revealed by spectral depolarization [6864-15]

D. D. Duncan, Oregon Health and Science Univ. (USA); M. E. Thomas, Johns Hopkins Univ. (USA)

$6864 \mathrm{OH}$ Finite difference time-domain model of light scattering from retinal photoreceptors [6864-16]

S. Abdallah, A. Iolov, O. M. Ramahi, K. Bizheva, Univ. of Waterloo (Canada)

6864 Ol Adaptive spectral window sizes for feature extraction from optical spectra [6864-17] C.-W. Kan, The Univ. of Texas (USA); A. Y. Lee, The Univ. of Texas at Austin (USA); N. Pham, L. T. Nieman, K. Sokolov, M. K. Markey, The Univ. of Texas (USA)

\section{SESSION 5 ANIMAL STUDIES}

6864 OK Relationship between light scattering and absorption due to cytochrome c oxidase reduction during loss of tissue viability in brains of rats [6864-19]

S. Kawauchi, S. Sato, H. Ooigawa, H. Nawashiro, M. Ishihara, M. Kikuchi, National Defense Medical College (Japan)

$68640 \mathrm{M}$ Optical visualization of stimulus-evoked fast neural activity and spreading waves in amphibian retina [6864-21]

X.-C. Yao, Y.-B. Zhao, C. M. Gorga, Univ. of Alabama at Birmingham (USA)

6864 ON Evaluation of optical imaging and spectroscopy approaches for cardiac tissue depth assessment [6864-22]

B. Lin, Univ. of California, Davis (USA); D. Matthews, Univ. of California, Davis (USA) and Lawrence Livermore National Lab. (USA); V. Chernomordik, A. Gandjbakhche, National Institutes of Health (USA); S. Lane, S. Demos, Univ. of California, Davis (USA) and Lawrence Livermore National Lab. (USA)

6864 OP Measuring neoplastic transformation in the hamster cheek pouch using Fourier domain low-coherence interferometry [6864-24]

R. N. Graf, Duke Univ. (USA); X. Chen, Biomedical/ Biotechnology Research Institute, North Carolina Central Univ. (USA); W. Brown, A. Wax, Duke Univ. (USA)

\section{SESSION $6 \quad$ IN VITRO CELL STUDIES}

6864 OS Phenotypic analysis of bacterial colonies using laser light scatter and pattern-recognition techniques [6864-27]

B. Rajwa, B. Bayraktar, P. P. Banada, K. Huff, E. Bae, E. D. Hirleman, A. K. Bhunia,

J. P. Robinson, Purdue Univ. (USA) 
6864 OT Studying cell dynamics and function with CLASS microscopy (Invited Paper) [6864-28]

L. Qiu, E. Vitkin, S. Salahuddin, B. S. Turner, S. E. Keates, M. D. Modell, Beth Israel Deaconess Medical Ctr., Harvard Univ. (USA); R. Bansil, Boston Univ. (USA); I. Itzkan, Beth Israel

Deaconess Medical Ctr., Harvard Univ. (USA); E. B. Hanlon, Dept. of Veterans Affairs (USA);

L. T. Perelman, Beth Israel Deaconess Medical Ctr., Harvard Univ. (USA)

\section{SESSION 7 DYNAMIC AND TIME RESOLVED METHODS}

6864 OW Clinically compatible time-resolved diffuse spectroscopy in the 600-1100-nm bandwidth [6864-31]

A. Bassi, A. Farina, C. D'Andrea, A. Pifferi, G. Valentini, R. Cubeddu, Politecnico di Milano (Italy)

POSTER SESSION

6864 OY Signal sources in elastic light scattering by biological cells and tissues: what can elastic light scattering spectroscopy tell us? [6864-34]

M. XU, Fairfield Univ. (USA); T. T. WU, J. Y. QU, Hong Kong Univ. of Science and Technology (Hong Kong China)

$6864 \mathrm{OZ}$ A universal numerical treatment of radiative transport equations with differential and integral scattering operators [6864-35]

K. G. Phillips, The CUNY Graduate Ctr. (USA); C. Lancellotti, The CUNY Graduate Ctr. (USA) and The College of Staten Island (USA)

686410 Time-resolved optical spectroscopic quantification of red blood cell damage caused by cardiovascular devices [6864-36]

D. Sakota, Tokyo Medical and Dental Univ. (Japan); R. Sakamoto, Sophia Univ. (Japan); H. Sobajima, N. Yokoyama, Y. Yokoyama, S. Waguri, K. Ohuchi, S. Takatani, Tokyo Medical and Dental Univ. (Japan)

686411 Rapid detection of bacterial cells by light scattering method [6864-37]

O. I. Bilyy, V. B. Getman, The Ivan Franko National Univ. of Lviv (Ukraine); R. O. Bilyy, Institute of Cell Biology (Ukraine); I. M. Kushnir, I. Ya. Kotsiumbas, State Scientific-Research Control Institute of Veterinary Preparations and Fodder Additives (Ukraine)

686412 Laser scatter in clinical applications [6864-39]

E. Luther, CompuCyte Corp. (USA); W. Geddie, Univ. Health Network (Canada)

686413 Estimation of absorption coefficient in bottom regions in multi-layered turbid media based on the time-domain depth sensitivity: a Monte Carlo investigation [6864-40]

C. Sato, Tokyo Institute of Psychiatry (Japan); M. Shimada, Institute for Molecular Science (Japan); Y. Hoshi, Tokyo Institute of Psychiatry (Japan) 
686414 Simultaneous iterative reconstruction technique for diffuse optical tomography imaging: iteration criterion and image recognition [6864-41]

Z.-H. Yu, Industrial Technology Research Institute (Taiwan) and National Taiwan Univ. (Taiwan); C.-M. WU, Y.-W. Lin, National Taiwan Univ. (Taiwan); M.-L. Chuang, China Medical Univ. Hospital (Taiwan) and School of Medicine, China Medical Univ. (Taiwan); J. Tsai, National Taiwan Univ. (Taiwan); C.-W. Sun, Industrial Technology Research Institute (Taiwan)

686415 Diagnosis of cardiovascular diseases based on diffuse optical tomography system [6864-42]

Z.-H. YU, Industrial Technology Research Institute (Taiwan) and National Taiwan Univ. (Taiwan); C.-M. WU, Y.-W. Lin, National Taiwan Univ. (Taiwan); M.-L. Chuang, China Medical Univ. Hospital (Taiwan) and School of Medicine, China Medical Univ. (Taiwan); J. Tsai, National Taiwan Univ. (Taiwan); C.-W. Sun, Industrial Technology Research Institute (Taiwan)

686416 Chemometric techniques on the analysis of Raman spectra of serum blood samples of breast cancer patients [6864-43]

L. N. Rocha-Osornio, J. L. Pichardo-Molina, O. Barbosa-Garcia, C. Frausto-Reyes,

C. Araujo-Andrade, Ctr. de Investigaciones en Óptica, A.C. (Mexico); R. Huerta-Franco,

G. Gutiérrez-Juárez, Univ. de Guanajuato (Mexico)

686417 Discrimination of normal and dysplasia in cervix tissue by Mueller matrix analysis [6864-44] P. Shukla, A. Awasthi, P. K. Pandey, A. Pradhan, Indian Institute of Technology Kanpur (India)

Author Index 


\title{
Conference Committee
}

\author{
Symposium Chairs \\ James Fujimoto, Massachusetts Institute of Technology (USA) \\ R. Rox Anderson, Wellman Center for Photomedicine, Massachusetts \\ General Hospital (USA) and Harvard School of Medicine (USA)
}

Program Track Chairs

Ammasi Periasamy, University of Virginia (USA)

Daniel L. Farkas, Cedars-Sinai Medical Center (USA)

Conference Chairs

Adam Wax, Duke University (USA)

Vadim Backman, Northwestern University (USA)

Program Committee

Irving J. Bigio, Boston University (USA)

Stephen A. Boppart, University of Illinois at Urbana-Champaign (USA)

Thomas H. Foster, University of Rochester (USA)

Steven L. Jacques, Oregon Health and Science University (USA)

Lev T. Perelman, Harvard Medical School (USA)

Brian W. Pogue, Dartmouth College (USA)

Bruce J. Tromberg, Beckman Laser Institute and Medical Clinic (USA)

Session Chairs

$1 \quad$ New Approaches

Vadim Backman, Northwestern University (USA)

2 Low Coherence Light Scattering

Stephen A. Boppart, University of Illinois at Urbana-Champaign (USA)

Daniel L. Marks, University of Illinois at Urbana-Champaign (USA)

3 Clinical and Preclinical Studies

Adam Wax, Duke University (USA)

4 Theory

Lev T. Perelman, Harvard Medical School (USA)

5 Animal Studies

Adam Wax, Duke University (USA) 
6 In Vitro Cell Studies

Thomas H. Foster, University of Rochester (USA)

$7 \quad$ Dynamic and Time Resolved Methods

Adam Wax, Duke University (USA)

Poster Session

Adam Wax, Duke University (USA) 